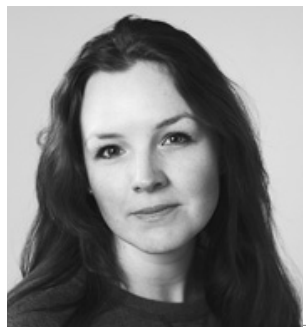

Hanne Støre Valeur (f. 1982) er konstituert

publiseringsredaktør i Tidsskrift for Den norske

legeforening.

Foto: Einar Nilsen

Tidsskriftet er Legeforeningens medlemsblad - og en vitenskapelig publikasjon. For å opprettholde en troverdig profil som medisinsk tidsskrift kreves bevissthet rundt redaktørens rolle og hva redaksjonell frihet innebærer

\title{
Sikker redaksjonell frihet
}

Tidsskrift for Den norske legeforening er mer enn et medlemsblad det er et medisinskvitenskapelig tidsskrift som publiserer ny forskning, oppsummert medisinsk kunnskap og faglig og helsepolitisk debattstoff $\mathrm{i}$ tråd med målsettingen (1). For å utføre disse oppgavene på en troverdig måte er det riktig og viktig at vurderingene av hva som skal publiseres, skjer på et uavhengig grunnlag. For Tidsskriftet vil det si uavhengig av hva vår eier Legeforeningen som helse- og samfunnspolitisk aktør måtte mene og ønske. Slik redaksjonell uavhengighet er i dag slått fast i Legeforeningens lover med at Tidsskriftet skal redigeres etter redaktørplakaten (2).

I redaktørplakaten kan vi lese: «En redaktør forutsettes å dele sitt mediums grunnsyn og formåls-bestemmelser. Men innenfor denne rammen skal redaktøren ha en fri og uavhengig ledelse av redaksjonen og full frihet til å forme mediets meninger, selv om de i enkelte spørsmål ikke deles av utgiveren eller styret» (3). Det du leser i Tidsskriftet, er dermed ikke et produkt tilpasset Legeforeningens kommunikasjonsstrategi, men et resultat av redaksjonelle vurderinger ut fra den redaksjonelle linje som til enhver tid bestemmes av sjefredaktøren (4). Som vitenskapelig publikasjon har Tidsskriftet også forpliktet seg til å følge anbefalingene til International Committee of Medical Journal Editors (ICMJE) (5). Dette er en samling sjefredaktører fra ledende medisinske publikasjoner, best kjent som Vancouvergruppen, som utformer og oppdaterer anbefalinger for hvordan medisinske tidsskrifter bør forholde seg i sitt arbeid med å publisere medisinskvitenskapelig informasjon. Tidsskriftets sjefredaktør har siden 1978 og frem til ganske nylig vært en del av denne gruppen.

Charlotte Haug, sjefredaktør gjennom 13 år, gikk nylig av fra sin stilling etter det som beskrives som uenighet mellom Legeforeningen og Haug om ledelse, drift og administrasjon av Tidsskriftet (6-9). Flere sjefredaktører i ledende internasjonale medisinske tidsskrifter har uttrykt bekymring for prosessen som førte frem til Haugs avgang (9). Det er klart at forholdet mellom Tidsskriftet og Legeforeningen per i dag ikke er organisert på en måte som til fulle følger Vancouvergruppens anbefalinger, særlig når det gjelder redaktørens ansettelsesforhold (5). Vancouvergruppen anbefaler at slike avgjørelser tas av et panel av uavhengige eksperter, heller enn av foreningens operative ledelse. Et panel med slik myndighet eksisterer ikke per i dag. Et uavhengig panel vil sikre at årsaken til at en redaktør skiftes ut ikke ligger i en artikkel eller en redaksjonell linje som slår uheldig ut for eieren, og vil dermed være et vern av den redaksjonelle friheten. Haugs avgang og måten den foregikk på, har ført til tap av omdømme og internasjonal anerkjennelse for Tidsskriftet, og vi har ikke lenger en posisjon i Vancouvergruppen. Vår forpliktelse til å følge gruppens anbefalinger er allikevel den samme.

Mot denne bakgrunn er det på sin plass at Legeforeningens sentralstyre nå fremmer forslag til årets landsstyremøte om å sette ned en komité som får i oppdrag å vurdere alle sider av forholdet mellom
Tidsskriftet og Legeforeningen som eier. I tillegg til å se nærmere på rutiner for hvordan redaktøren bør ansettes og konflikter håndteres er det også god grunn til å vurdere om dagens organisering er hensiktsmessig. I dag anses driften av Tidsskriftet som en del av foreningens daglige virksomhet, og redaksjonens medarbeidere er ansatt i sekretariatet (2). Dagens organisering innebærer uklare grenser mellom hva som ligger under redaktørens ansvarsområde og beslutningsmyndighet og hva som hører til hos generalsekretæren når det gjelder administrasjon, drift og økonomiske prioriteringer. Man bør også se nærmere på om den redaksjonelle friheten er godt nok sikret når redaksjonens medarbeidere, inkludert alle de medisinske redaktørene, er ansatt hos generalsekretæren, som rapporterer til Legeforeningens sentralstyre.

Hva redaksjonell frihet faktisk innebærer, er et spørsmål uten enkle svar og et spørsmål som er blitt enda mer komplisert å svare på nå som medievirkeligheten i større grad befinner seg på internett, uavhengig av statiske papirversjoner. Publisering på nett gir flere valgmuligheter for hvordan innholdet presenteres og spres, valg som kan være essensielle for at budskapet skal formidles slik det var ment. Det er selvsagt at sjefredaktøren skal bestemme hvilke ord og hvilket innhold som skal publiseres, men hvem bestemmer hvor - i hvilke kanaler, når og i hvilken sammenheng innholdet skal frigis? Hvem bestemmer i de viktige strategiske, utviklingsmessige valgene som er vesentlige for å overleve i den konkurranseutsatte medievirkeligheten Tidsskriftet er en del av? Redaktøren må ha det nødvendige handlingsrom for å sørge for at Tidsskriftet utvikler seg i takt med de krav og forventninger som stilles til et moderne vitenskapelig medium. Et slikt handlingsrom er avgjørende for at den redaksjonelle friheten skal være reell.

For at Tidsskriftet skal ha en posisjon som en troverdig og profesjonell medisinsk publikasjon, er det nødvendig med en gjennomgang av dagens organisering og en grundig vurdering av hvordan vi best sikrer den redaksjonelle friheten.

\footnotetext{
Litteratur

. Tidsskrift for Den norske legeforening. Om Tidsskriftet. http://tidsskriftet.no/ Meta/Om-Tidsskriftet (28.3.2015).

2. Legeforeningen. Den norske legeforenings lover § 4-2. https://legeforeningen.no/Om-Legeforeningen/Organisasjonen/dnlf-lover/ den-norske-legeforenings-lover/ (28.3.2015).

3. Norsk redaktørforening. Redaktørplakaten. www.nored.no/Redaktoeransvar/ Redaktoerplakaten (28.3.2015).

4. Hem E. Hva mener Legeforeningen? Tidsskr Nor Legeforen 2013; 133: 1041

5. International Committee of Medical Journal Editors. Recommendations for the Conduct, Reporting. Editing, and Publication of Scholarly work in Medical Journals. http://www.icmje.org/recommendations/ (28.3.2015).

6. Haug C. Takk for meg. Tidsskr Nor Legeforen 2015; 135: 301.

7. Johansen GS. Munnkurv om redaktøravgang. Journalisten. http://journalisten.no/2015/02/tidsskriftet-redaktor-slutter (28.3.2015)

8. Time JK. Skaden er uopprettelig. Morgenbladet 13.2.2015. http://morgenbladet.no/ samfunn/2015/skaden_er_uopprettelig\#.VR2jDaM4W5s (28.3.15).

9. Kmietowicz Z. Editor in chief of Journal of the Norwegian Medical Association resigns. BMJ 2015; 350: h766.
} 